Contents List available at VOLKSON PRESS
Education, Culture and Social Development (ECSD)
DOI : http://doi.org/10.26480/icecsd.01.2018.36.37
Journal Homepage: : https://topicsonsocialdevelop.com/

\title{
A CROSS-CULTURE STUDY ON CHINESE AND ENGLISH IN CHINESE CONTEXT
}

\author{
Ma Zhenyu \\ Foreign Language department, Guilin University of Technology No. 319, Yanshan Street, Guilin, China. \\ *Corresponding Author Email: 1502710279@qq.com
}

This is an open access article distributed under the Creative Commons Attribution License, which permits unrestricted use, distribution, and reproduction in any medium, provided the original work is properly cited

\section{ARTICLE DETAILS}

\section{Article History:}

Received 12 November 2017 Accepted 12 December 2017 Available online 1 January 2018

\section{ABSTRACT}

Based on previous research that the younger generations have a misunderstanding about the way typical Chinese expressed in English, this study discussed the possibility and rationality of appropriateness of English use in Chinese context through three aspects. Firstly, Western sinologists set good models for Chinese people to follow; Secondly, Chinese people's uncomfortableness is actually from our incompetence of appreciating Chinese culture; Thirdly, English cultural conventions are not set as the only rules to restrict Chinese people to communicate typical Chinese culture. From the discussion it concluded that English variants should also apply to Chinese culture so that we have confidence in using English in Chinese context.

\section{KEYWORDS}

Cross-Culture, Chinese Context, English Variant

\section{INTRODUCTION}

Previous research shows that there has been little introduction in how to express Chinese culture in English study, or contents about Chinese culture are purposely avoided so that students can form a habit of English thinking. Later research proposes that if the teacher stresses the importance of how to express Chinese culture in English, it might work. However, there's been few empirical studies to support it. Some theorybased studies reveal that Chinese students feel uncomfortable to express typical Chinese culture in English, thinking that it's improper because they are two sets of language systems and they are not quite sure whether the native speakers work that way.

\section{PURPOSE OF THIS STUDY}

The overemphasis on the importance of English and English culture has caused the consequences that the younger generations lack knowledge in traditional Chinese culture, history, literature; that Chinese culture cannot be properly expressed in English; and even worse is that, they advocate the English and other western languages and their cultures but have no sense of identity in Chinese culture.

English has been a compulsory course in middle schools and universities across China, but how to express our own culture in English is now a big challenge. In order to make China and Chinese people and Chinese culture better known to, and better understood by the outside world, and most importantly, to make Chinese younger generations have confidence in our own culture and the cognition that typical Chinese can be expressed properly in English, this study aims to argue and discuss the possibility and rationality of China English, an English variant.

\section{DISCUSSION}

Every culture is unique, and the uniqueness of Chinese culture determines its unique position and its unique set of language systems to carry it. English is quite different from Chinese because it's the carrier of the English culture. However, the two language speakers have to interact in all aspects of life.

\subsection{Western sinologists' works}

Without the Italian missionary Matteo Ricci, the world doesn't know 孔子 . Confucius and Confucianism are typical local culture, how was it made known to the western world? It is just because it was put in the western language that the essence of our traditional culture was widely spread to the outside world, so that both language speakers now find it natural to use the English expressions like Confucius, Confucian, Confucianism, and Mencius.

Many other sinologists have also done great contributions to spread Chinese culture to western countries besides Matteo Ricci. The book Overseas Chinese Research Series listed 642 sinologists including James Harrison Wilson's China (1901); Juliet Bredon's The Moon Year: A Record of Chinese Customs and Festivals (1927) and Chinese New Year Festivals (1930); Edgar Parks Snow's Red Star over China (1938); James Roland Ware's the Sayings of Confucius, The Sayings of Mencius (1955); Cheste Ronning's A Memoir of China in Revolution from the Boxer Rebellion to People's Republic (1973) etc.

In their works, they introduced typical Chinese terms like 占卜(divination) 、赌博 (gambling)、和尚 (monk)、迷信 (superstition)、礼节(etiquette) 、鸦片 (opium)、风水 (fengshui)、打油诗(doggerel) etc. In David L. Hall and Roger T. Ames's Thinking through Confucius, the Confucian thought of "human"(人)，"benevolence"（仁）, "At forty, no doubts"(四十不惑) and "At Fifty, the mandate of heaven" were analyzed [1]. Herbert Fingarette's Confucius: The Secular as Sacred show us what is contained in the Analects of Confucius like "etiquette for the monarch, the father and the son of the man" [2].

From Matteo Ricci in the Ming Dynasty to present day Howard Goldblatt ( 葛浩文) who introduced typical Chinese culture in Mo Yan's books, these sinologists have set good models in expressing Chinese culture for us to follow. Chinese in their works are from the minds of native speakers and are supposed to be easily understood by the western world.

\subsection{The Sense of Chinese culture identity}

Culture identity means the approval and appreciation of one's culture. If we have little knowledge of our own culture, we simply cannot appreciate it. The investigation reveals that college students score only $57.16 \%$ in a comprehensive Chinese culture test which included the way of thinking, customs, beliefs and ideas [3]. And some even say the Axial Age (200BC800 BC) equals to China's Tang Dynasty (618-907) and Confucius, Lao Tzu and Mo-tse lived in this period. Obviously, the lack of Chinese knowledge restricts our approval and appreciation.

Communications should be bi-directional and move forward in a balanced way. The culture of English has opened up another window for us to 
understand the outside world and has expanded our vision, but we should not passively accept foreign cultures without spreading our own culture. We should not be passive and always be listeners and lose the right to speak. We should voice and stop the one-way activity of communications. We must dispel cultural centralism, and truly return to Chinese context.

\subsection{Cultural conventions}

Though appropriateness of language use is restricted by culture. However, there are special circumstances in each country [4]. If all the countries that communicate in English have to abide by the pragmatic rules of the English language, communications will not be achieved. A group researches pointed out that the reverse cultural adaptation behavior of foreigners in mainstream culture is obvious [5]. Other researcher proposes that the appropriateness of speech acts in intercultural communications cannot be entirely determined by what language to use [6]. Therefore, the use of English may not always follow the culture of the English nation, but also follow the culture of the country in which the English language is used. American English is an English that is not entirely equivalent to native British English, and also Canadian English, Singapore English, Indian English, Australian English, New Zealand English and there might be a long list. Each country has a variety of English variants.

Some researcher discussed the cultural stipulation of English in Chinese context [7]. He believes that in a multicultural pattern, we should not only be sensitive to western culture, but also maintain a high degree of selfawareness and confidence in our culture [8]. In China, we speak English in our formatted expressions with caution and in a low profile. In the longterm competition of language power, the English model in the Chinese context is only American and British English, little space left for China English.

So, in Chinese context, Chinese culture cannot be regulated in English culture. Chinese variant in English should be allowed, that is, localization of English application. Theoretically, we should maintain our uniqueness, at the same time find out the commonness and finally compatibility [9].

\section{CLOSING REMARKS}

In the process of globalization, we should have an open mind, not only to embrace foreign cultures, learn their cultures, but also cultivate a sensitivity to their cultures and language. At the same time, in crosscultural activities, we must have our own culture identity and culture confidence. If the usual cultural differences and the language barriers are solved, misunderstanding in cross-cultural communications will be reduced and cross-cultural communications will be facilitated.

\section{REFERENCES}

[1] Hall, D.L., Ames, R.T. 1987. Thinking through Confucius. Beijing: Sunny Press, 495-503.

[2] Fingarette, H. 2010. Confucius: The Secular as Sacred (M). New York: Harper \& Row, 463-477.

[3] Fulong, X., Di, X., Lan, L., Yiwen, S. 2010. A study of Chinese cultural aphasia in English education in Chinese Universities. The Theory and Practice of Foreign Language Teaching, 1, 39-46.

[4] Zhijun, X. 1995. China English: interference variant in intercultural communication (J). In Modern foreign language, 7-11.

[5] Yonghoing, H. 2009. A reverse study on intercultural adaptation theory. In Foreign Language Research, 4, 88-91.

[6] Lisheng, X. 2000. A discussion on the problem of intercultural communication ability. Foreign Languages and Their Teaching, 7, 17-21.

[7] Yuexiang, X. 2017. The cultural motivation of the localization of English in the contemporary context, 67-69.

[8] Yonghao, W. 2016. The learning of the knowledge community----The importance of returning to the Chinese Context. In Academy Monthly 12, 5-13.

[9] Cong, C. 2000. Chinese cultural aphasia: defects in English Teaching in China. Guangmimg Daily, 19. 